\title{
Phenotypic characteristics of Indonesian native chickens
}

\author{
Achmad Rofii - Tyas Rini Saraswati - Enny Yusuf Wachidah Yuniwarti
}

\author{
A Rofii (Corresponding author) - TR Saraswati - EYW \\ Yuniwarti \\ Department of Biology, Faculty of Mathematics and Natural \\ Science, Diponegoro University, Campus Tembalang \\ Semarang City, Central Java, Indonesia.
}

email: ahmadrofii290@gmail.com

Received: November 24, 2017 • Revised: December 15, 2017 • Accepted: December 29, 2017

\begin{abstract}
This research aimed to describe the phenotypic characteristics of local hen varieties. The study sample consisted of twenty 18 week-old hens of the following types: Cemani, black Kedu, white Kedu, and Balinese (Olagan). They were randomly selected from the "Makukuhan" farm in Kedu Temanggung, Central Java Indonesia. The results, which were analyzed using analysis of variance (ANOVA) test, showed significant differences in the quantitative characteristics of body height, body length, and tarsometatarsus length. No significant differences were found in wing length, beak length, femur length, tibiotarsus length, or body weight. Qualitative characteristics of Cemani hens differed from those of black Kedu, white Kedu, and Balinese (Olagan) hens because of their predominantly black body color. The black Kedu hens share similarities with the white Kedu hens in the colors of the tongue, comb, eyeballs, and soles of the feet. In contrast, their beak color and skin color are similar to those of the Balinese (Olagan) hens. The white Kedu hens have predominantly white feathers, and the Balinese (olagan) hens have neither comb nor neck feathers.
\end{abstract}

Keywords: Balinese (Olagan) hen, black Kedu hen, Cemani hen, phenotypic characteristics, white Kedu hen

\section{Introduction}

Indonesia has 31 types of local chicken, which have distinct phenotypic characteristics. Differences in the chicken phenotypes are allegedly due to genetic differentiation of populations caused by migratory demographics (Nataamijaya 2000). The types of local chicken are black Kedu, white Kedu, Cemani and Balinese (Olagan) (Ismoyowati et al 2012). According to Sartika et al (2004), the Kedu and Kampong chicken types share a common ancestor, namely the Red junglefowl (Gallus gallus). The Cemani chicken is a type of Kedu chicken with a predominantly black body color. Phenotypical characteristics chickens are influenced by genes and environmental factors (Johari et al 2009; Mahfudz et al 2011).

Phenotypical characteristics are aspects of physical appearance or other properties that can be measured qualitatively and qualitatively (Nthimo et al 2004). The Identification of the phenotypical characteristics of local chickens is indispensable to genetic improvement programs. One way to identify the various types of chickens is by observing quantitative physical characteristics (height, body length, length of beak, wing length, and body weight) and qualitative characteristics (color of feathers, skin, tongue, foot, and comb). A genetic diversity study can be used to analyze a regional population for conservation purposes (Zanetti et al 2010).

According to Sulandari et al (2008), the Cemani, black Kedu, white Kedu, and Balinese (Olagan) chickens serve locally as ornamental chickens, production chickens, and chicken fighters, respectively, the latter because of its strength and body type. Local Indonesian chickens have special phenotypical characteristics; therefore, specific phenotypical character identification is required to as certain the genetic diversity of the local chicken population and for the development of a germplasm. Riztyan et al (2011) states that local chickens in Indonesia are kept in small groups has the distinction of a low character.

In this study, we aim characterize of the phenotypes of 18-week-old hens of the Cemani, black Kedu, white Kedu, and Balinese (Olagan) chicken varieties.

\section{Materials and Methods}

A total of 20 hens were included in this study, 5 each from the four local chicken varieties Cemani, black Kedu, white Kedu, Balinese (Olagan). The chickens were procured from "Makukuhan" farms in Kedu Temanggung, Central Java, Indonesia, at the age of 18 weeks. Chickens were treated identically, housed in cages of size $50 \times 50 \times 40 \mathrm{~cm} / 5$ hens age of 1-4 weeks, $75 \times 75 \times 60 \mathrm{~cm} / 5$ hens age of 4-12 weeks and $120 \times 100 \times 75 \mathrm{~cm} / 5$ hens age of $12-18$ weeks and feed composed 
of Corn:Bran:Concentrate, (3:4:3). The proximate analysis of feed on table 1. Drinking water was provided ad libitum.

The quantitative phenotypical characteristics of body height, body length, beak length, wing length, length of shank segments (femur, tibiotarsus, and tarsometatarsus), and body weight and the qualitative phenotype characteristics of beak, tongue, comb, skin, eye, and foot color, as well as the colors of the soles of the feet, and the feathers of the neck were observed.

Quantitative characters were analyzed using Analysis of Variance (ANOVA) followed by Duncan's test $(\mathrm{P}=0.05)$.

Table 1 Proximate analysis of feed.

\begin{tabular}{cccccc}
\hline \multirow{2}{*}{ Sample } & \multicolumn{5}{c}{ Parameters } \\
\cline { 2 - 6 } & Protein $(\%)$ & Fat $(\%)$ & Water $(\%)$ & Ash $(\%)$ & ME (kal/g) \\
\hline \multirow{2}{*}{1} & 11,1 & 5,43 & 11,39 & 7,37 & 3567,73 \\
2 & 12,18 & 5,54 & 12,42 & 8,41 & 3628,42 \\
\hline
\end{tabular}

Table 2 The means of environmental temperature during study.

\begin{tabular}{cccccc}
\hline \multirow{2}{*}{ Time } & \multicolumn{5}{c}{ Months } \\
\cline { 2 - 5 } $08.00 \mathrm{am}$ & Jun & Jul & Aug & Sept & Oct \\
\hline $10.00 \mathrm{am}$ & $25,3^{\circ} \mathrm{C}$ & $23,7^{\circ} \mathrm{C}$ & $22,5{ }^{\circ} \mathrm{C}$ & $20,8{ }^{\circ} \mathrm{C}$ & $23,7{ }^{\circ} \mathrm{C}$ \\
$12.00 \mathrm{am}$ & $34,2{ }^{\circ} \mathrm{C}$ & $26,3{ }^{\circ} \mathrm{C}$ & $27,7{ }^{\circ} \mathrm{C}$ & $27,6{ }^{\circ} \mathrm{C}$ & $28,5{ }^{\circ} \mathrm{C}$ \\
$14.00 \mathrm{pm}$ & $33,3^{\circ} \mathrm{C}$ & $34,5{ }^{\circ} \mathrm{C}$ & $34,8{ }^{\circ} \mathrm{C}$ & $34,2{ }^{\circ} \mathrm{C}$ \\
$16.00 \mathrm{pm}$ & $32,3{ }^{\circ} \mathrm{C}$ & $32,3{ }^{\circ} \mathrm{C}$ & $33,0{ }^{\circ} \mathrm{C}$ & $30,8{ }^{\circ} \mathrm{C}$ & $33,2{ }^{\circ} \mathrm{C}$ \\
$20.00 \mathrm{pm}$ & $27,0{ }^{\circ} \mathrm{C}$ & $28,3{ }^{\circ} \mathrm{C}$ & $27,7{ }^{\circ} \mathrm{C}$ & $26,6{ }^{\circ} \mathrm{C}$ & $27,0{ }^{\circ} \mathrm{C}$ \\
\hline
\end{tabular}

\section{Results and Discussion}

Quantitative characteristics

The results of ANOVA for the quantitative phenotypical characteristics of Cemani, black Kedu, white Kedu, and Balinese (Olagan) hens at 18 weeks are show in table 1 .

The body height, body length, tarsometatarsus length and feed consumption were significantly different $(P$ $>0.05$ ), while the wing length, beak length, femur length, tibiotarsus length, and body weight showed no significant differences ( $\mathrm{P}<0.05)$. Results of the Duncan test showed that between Cemani, black Kedu, and white Kedu hens there was no difference in body height, body length or tarsometatarsus length, the Balinese (Olagan) hens showed a significant difference. There were differences in feed consumption between Cemani, black Kedu, white Kedu, and Balinese (Olagan) hens. Cemani hens consumed the least feed (90.4 g), while Balinese (Olagan) hens consumed the most (97.6 g).

The factors affecting the variation in phenotypical characteristics are genes and environmental conditions
(Fayeye et al 2006; Johari et al 2008; Mahfudz et al 2011). Based on their origins, Cemani, black Kedu, white Kedu, and Kampong chickens are derived from a common ancestor the Red junglefowl (Gallus gallus) (Sulandari et al 2008; Alwi et al 2014). The genetic distance between chicken types can affect the phenotypic characteristics like body length and body size (Mariandayani et al 2013). Kedu chickens have high genetic diversity and genetically distant from other chickens (Ismoyowati et al 2012). According to Tadono et al (2007) degradation of genetic variability is caused by maintenance in the same environments; thus, in the caracteristics of beak, wing, femur, and tibiotarsus length there is no longer any variation.

Differences in body height, body length, and tarsometatarsus length in Cemani, black Kedu, white Kedu and Balinese (Olagan) hens are affected by environmental factors. The weather and environmental temperature $\left[35^{\circ} \mathrm{C}\right.$ (noon) and $15^{\circ} \mathrm{C}$ (night)] in the last month (figure 2) of study period may have been the reason for some Cemani chickens contracting the Snot (Coryza) causing decreased feed consumption and stunted growth (Chukiatsiri and Chansiripornchai 2008; Welchman et al 2010). 
Table 3 Quantitative phenotypical characteristics of Cemani, black Kedu, white Kedu, and Balinese (Olagan) hens.

\begin{tabular}{|c|c|c|c|c|}
\hline \multirow{2}{*}{ Parameters } & \multicolumn{4}{|c|}{ Mean \pm St. Dev } \\
\hline & Cemani & Black Kedu & White Kedu & Olagan \\
\hline Body height (cm) & $25,60 \pm 0,548^{\mathrm{b}}$ & $25,20 \pm 0,447^{b}$ & $25,20 \pm 0,447^{b}$ & $28,40 \pm 0,548^{\mathrm{a}}$ \\
\hline Body length (cm) & $37,40 \pm 0,548^{b}$ & $37,20 \pm 0,447^{b}$ & $37,75 \pm 0,447^{b}$ & $39,75 \pm 0,447^{\mathrm{a}}$ \\
\hline Tarsometatarsus length $(\mathrm{cm})$ & $5,50 \pm 0,223^{\mathrm{b}}$ & $6,00 \pm 0,418^{b}$ & $6,00 \pm 0,447^{b}$ & $7,00 \pm 0,447^{\mathrm{a}}$ \\
\hline Feed consumption (g/d) & $90,40 \pm 1,673^{c}$ & $92,80 \pm 1,095^{\mathrm{b}}$ & $92,80 \pm 1,095^{b}$ & $97,60 \pm 1,673^{\mathrm{a}}$ \\
\hline Wing length $(\mathrm{cm})$ & $17,20 \pm 0,447$ & $17,30 \pm 0,274$ & $17,20 \pm 0,447$ & $17,30 \pm 0,548$ \\
\hline Beak length $(\mathrm{cm})$ & $2,960 \pm 0,089$ & $2,960 \pm 0,089$ & $2,960 \pm 0,223$ & $2,960 \pm 0,089$ \\
\hline Femur length $(\mathrm{cm})$ & $12,20 \pm 0,447$ & $12,00 \pm 0,000$ & $11,80 \pm 0,447$ & $12,40 \pm 0,548$ \\
\hline Tibiotarsus length $(\mathrm{cm})$ & $11,40 \pm 0,894$ & $11,00 \pm 0,000$ & $11,00 \pm 0,000$ & $11,80 \pm 0,447$ \\
\hline Body weight (g) & $1150 \pm 86,6$ & $1040 \pm 54,8$ & $1060 \pm 89,4$ & $1140 \pm 89,4$ \\
\hline
\end{tabular}

Note: Notation with the same lowercase letter same column indicates no significant difference $(\mathrm{P}>0.05)$ between samples.

Feed consumption in hens influences whole body metabolism and the process of bone formation (ossification). Ossification process begins with the formation of bone, which involves increased production of basic cellular constituents (osteoblasts and osteoclasts). Osteoblasts compose the surface layers of bone. An increase in bone thickness occurs through the addition of a layer of matrix generated by osteoblastic activity (Junqueira and Carneiro 2005). The function of protein in feed to form the internal scaffold of the cell called the cytoskeleton which is a network of protein filaments extending to the plasma membrane. The cytoskeleton supports and stabilizes cell shape, so if feed consumption decreases because of the disease, the rate growth can also decrease. (Solangi et al 2003; Samsudin et al 2012; Bangun et al 2013).

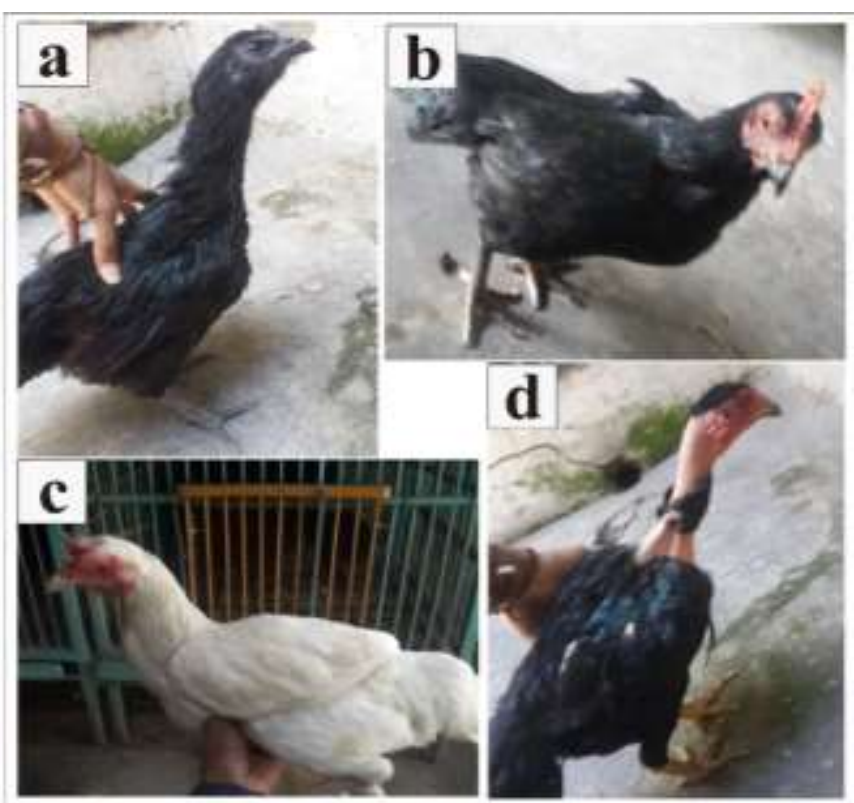

Figure 1 Types of local Indonesian hen, (a) Cemani hen, (b) black Kedu hen, (c) white Kedu hen, and (d) Balinese (Olagan) hen.
The average body weight of Cemani, black Kedu, white Kedu, and Balinese (Olagan) hens showed no significant difference because all the chicken ate the same type of feed and were maintained under identical conditions. According to Suthama (2006) The increase protein content in the feed affects the growth of chicken. Chickens fed identical diets show similiar live body wights, bet Cemani chikens are more efficient utilizing the nutrion in feed (Iskandar 2005).

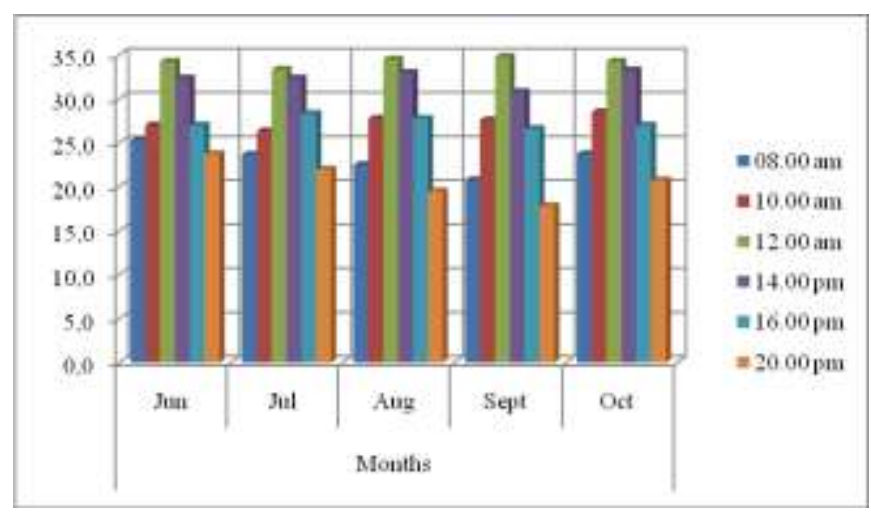

Figure 2 Environmental temperature during study.

Qualitative characteristics

Based on our observations of Cemani, black Kedu, white Kedu, and Balinese (Olagan) hens show high diversity in qualitative phenotypic characters (table 2).

Beak and Tongue color

Cemani, black Kedu, and Balinese (Olagan) hens all have black color beaks however in Balinese (Olagan) hens, black is not the dominant color. The white kedu hens has a white beak. 
Table 4 Qualitative phenotypical characteristics of Cemani, black Kedu, white Kedu, and Balinese (Olagan) hens.

\begin{tabular}{lcccc}
\hline \multirow{2}{*}{ Qualitative characteristics } & \multicolumn{3}{c}{ Strain } & Olagan \\
\cline { 2 - 5 } & Cemani & black Kedu & white Kedu & Black \\
Beak color & Black & Black & White & Gray \\
Tongue color & Black & Gray & Gray & - \\
Comb color & Black & Red & Red & Pale white \\
Skin Color & Black & Pale white & Pale white & Small black, orange \\
Eye color & Black dominant & Wide black, & Wide black, orange & Yellowish \\
Shanks color & Black & Black & White & Yellowish \\
Soles of the feet color & Black & Yellowish & Yellowish & White \\
Neck feathers color & Black & Black & & - \\
\hline
\end{tabular}
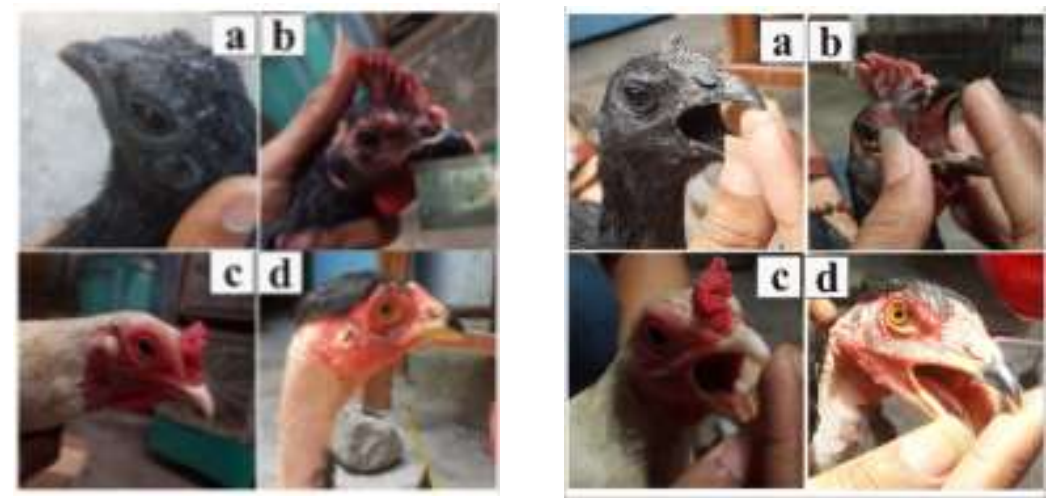

Figure 3 Beak and tongue color of (a) Cemani hen, (b) black Kedu hen, (c) white Kedu hen, and (d) Balinese (Olagan) hens.
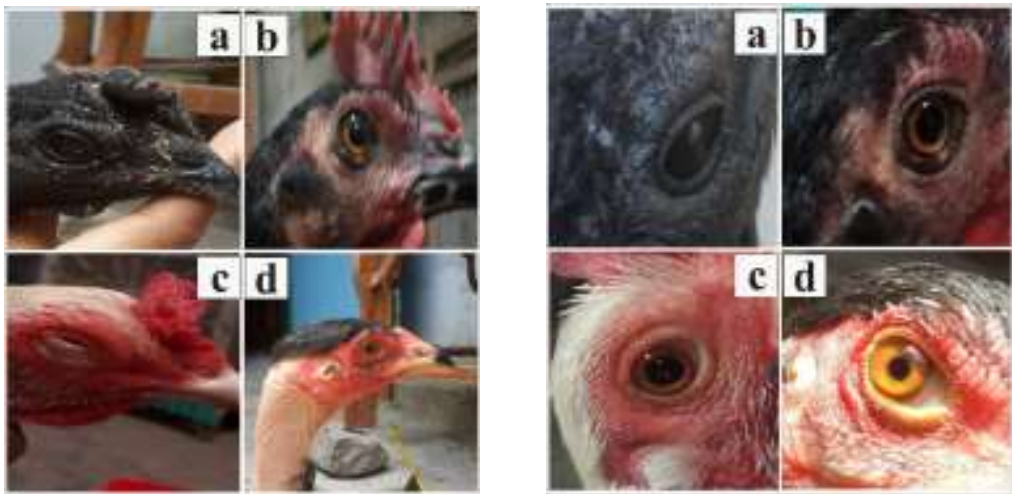

Figure 4 Comb and Eye color of, (a) Cemani hen, (b) black Kedu hen, (c) white Kedu hen, and (d) Balinese (Olagan) hens.

The tongue color of the Cemani hens is black, where as the black Kedu, white Kedu, and Balinese (Olagan) hens have gray tongues.

\section{Comb and Eye color}

The eyes and combs of Cemani hens are predominantly black. Black and white Kedu hens have red combs and wide black eyes circled in orange. Balinese (Olagan) hens have no comb and their eyes are small, black and circled in orange.

\section{Color of skin and Neck feathers}

Cemani hens have a predominantly black skin and feathers. Black Kedu, white Kedu, and Balinese (Olagan) hens 
have pale, white skin. Black and white Kedu hens have white neck feathers. Balinese (Olagan) hens have no neck feathers.

Color of shanks and sole

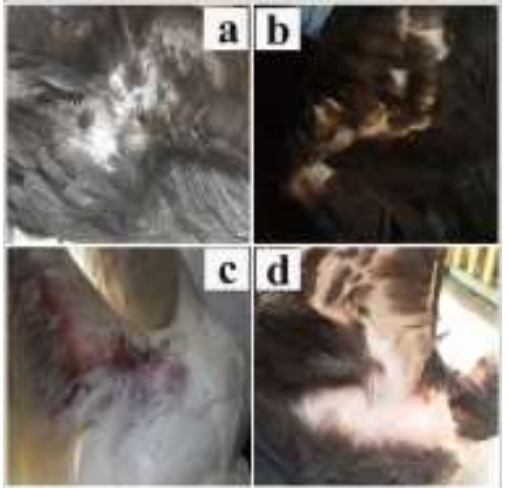

Cemani hens have the same shank color as black Kedu hens, but Cemani hens have black colored soles of feet, where as a black Kedu hen have yellowish soles of feet. White Kedu and Balinese (Olagan) hens yellowish legs and soles of feet.

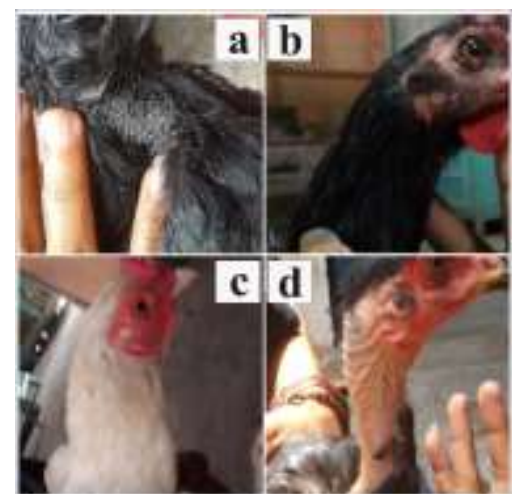

Figure 5 Skin and neck feathers colors of, (a) Cemani hen, (b) black Kedu hen, (c) white Kedu hen, (d) Balinese (Olagan) hens.
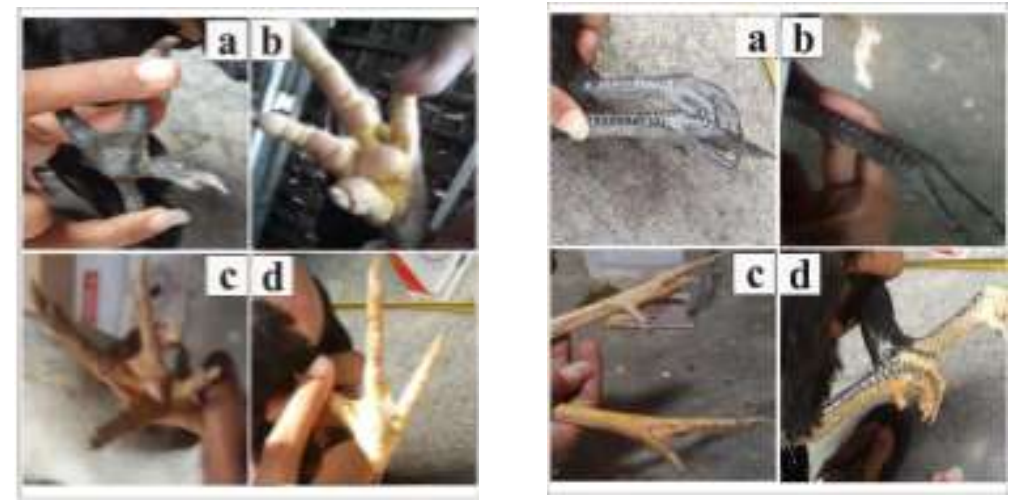

Figure 6 Color of shanks and soles of the feet of (a) Cemani hen, (b) black Kedu hen, (c) white Kedu hen, and (d) Balinese (Olagan) hen.

Differences in qualitative characteristics are due to genetoc factor, such as those mentioned by Sulandari et al (2008). The allele frequencies in the local chickens of Indonesia are high for these genetic factors. Phenotypical characteristics of the Kedu chicken based on genetic diversity and microsatellite markers showed a high level of diversity and a relatively large number of genetic relationship (Ismoyowati et al 2012). The appearance of qualitative phenotypical characteristic can be observed based on the colors of the feathers (black, red, white, and yellow), comb (gray, black and red), and skin (black and white). Comb shape in Kedu chickens has the same phenotype (Johari et al 2009).

\section{Conclusions}

Based on a phenotype characters test of Cemani, black Kedu, white Kedu, Balinese (Olagan) hens, it can be summed up that Cemani hens have the same quantitative phenotypical characteristic as black Kedu and white Kedu hens, but different from those of Balinese (Olagan) hens. Balinese (Olagan) hens have taller bodies, longer bodies and longer tarsometatarsus. The qualitative phenotypical characteristics of Cemani hens differ from those of the other hens in body color, their bodies are predominantly black. The penetypicel characteristics of Balinese (Olagan) hens differ quantitatively from those of Cemani, black Kedu, and white Kedu hens.

\section{Acknowledgements}

Authors thank to Makukuhan farms in Kedu Temanggung, Central Java, Indonesia and Department of Biology, Faculty of Mathematics and Natural Science, Diponegoro University who participated in this study. The authors also thank to Lembaga Penelitian dan Pengabdian kepada Masyarakat (LPPM), Diponegoro University for assisting with the English version of the manuscript.

\section{References}

Alwi M, Sumantri C, Darwati S (2014) The phenothypic and genetic characteristic of nunukan chicken of Tarakan island, east Borneo. Jurnal Veteriner 15:173-181. 
Bangun, GDD, Mahfudz, LD, Sunarti, D (2013) Effect of seaweed Gracilaria verrucosa meal utilization in broiler's diet on weight and size of Tibia and Tarsometatarsus. Animal Agricultural Journal 2:489-496.

Chukiatsiri K and Chansiripornchai N (2008) An outbreak of infectious coryza in a layer farm. J. Thai Vet. Med. Assoc. 58:98107.

Fayeye TR, Ayorinde KL, Ojo V, Adesina OM (2006) Frequency and influence of some major genes on body weight and size parameters of nigerian lokal chicken. Livestock Research for Rural Development 18:1-8.

Iskandar S (2005) Growth and carcass development of Kedu x Arab cross under two feeding regimes. JITV 10:253-259.

Ismoyowati, Sukardi, Susanto A (2012) Genetic diversity of kedu chicken based on phenotypic characteristics and microsatellite loci. International Journal of Poultry Science 11:605-610.

Johari S, Sutopo SA (2009) Phenotype frequency of the qualitative traits at adult Kedu chicken. http://eprints.undip.ac.id/16542/1/aPNR4-(36)Seno_Johari_1__setting.pdf. Accessed on: October 21, 2017.

Junqueira LC, Carneiro J (2005) Basic Histology: Text and Atlas. Ed ke- 11. Poule (Br): McGraw-Hill.

Mahfudz LD, Wulandari AR, Johari S (2011) Genetic variation through polymorphism of blood and egg white protein in three kinds of Kedu chickens at laying period. Animal Production 13:83-88.

Mariandayani HN, Solihin DD, Sulandari S, Sumatri C (2013) Phenotypic variation and estimation genetic distance between local chicken and broiler chicken using morphological analysis. Jurnal Veteriner 14:475-484

Nthimo AM, Neser FWC, du Toit JEJ, Fair MD, Odenya W (2004) Phenotypic characterization of indigenous chickens in Lesotho in the pre-laying phase. South African Journal of Animal Science 34:125127.

Riztyan, Katano T, Shimogiri T, Kawabe K, Okamoto S (2011) Genetic diversity and population structure of Indonesian native chickens based on single nucleotide polymorphism markers. Poultry Science 90:2471-2478.

Samsudin M, Sarengat W, Maulana HN (2012) The effect of difference in feeding period (starter - finisher) and protein level meat - bone ratio and protein mass of breast and thigh of pelung chicken from 1 to 11 weeks old of age. Animal Agricultural Journal 1:43-51.

Sartika T, Iskandar S, Prasetyo H, Takahashi H, Mitsuru M (2004) Genetic relationships of Kampung, Pelung, Sentul and Black Kedu Chicken using Microsatellite DNA Markers: I. Lingkage group of macro chromosome. JITV 9:81-86.

Solangi AA, Baloch GM, Wagan PK, Chachar B, Memon A (2003) Effect of different level of dietary protein on growth of broiler. J. of Anim. And Vet. Advances 2:301-304.

Sulandari S, Zein MSA, Astuti D, Sartika T (2009) Genetic polymorphisms of the chicken antiviral $\mathrm{Mx}$ gene in a variety of Indonesian indigenous chicken breeds. Jurnal Veteriner 10:50-56.

Sulandari S, Zein MSA, Sartika T (2008) Molecular characterization of Indonesian indigenous chickens based on mitochondrial DNA displacement (d)-loop sequences. Hayati Journal of Biosciences 15:145-154.

Suthama N (2006) Kajian aspek "protein turnover" tubuh ayam Kedu periode pertumbuhan. Media Peternakan 29:47-52.
Tadono R, Nishibori M, Nagasaka N, Tsudzuki M (2007) Assessing genetic diversity and population structure for commercial chicken lines based on forty microsatellite analyzes. Poultry Science 86:2301-2308.

Welchman DB, King SA, Wragg P (2010) Infectious coryza in chickens in Great Britain. Veterinary Record 167:912-913.

Zanetti E, De Marchi M, Dalvit C, Cassandro M (2010) Genetic characterization of local Italian breeds of chickens undergoing in situ conservation. Poultry Science 89:420-427. 